\title{
The Muscat Dhows Case in Historical Perspective
}

\section{Rodney Carlisle}

Une décision en 1905 de la Cour permanente d'arbitrage de La Haye, connu sous le nom $d u$ "cas des boutres de Muscat" avait résolu un différend entre les gouvernements français et britannique sur le droit de certains propriétaires de boutres omanais à battre le pavillon français, ce que les Britanniques prétendaient faire parti du commerce des esclaves dans l'océan indien. Le principe énoncé dans cette décision, que chaque état souverain a le droit d'allouer son pavillon maritime aux ressortissants d'autres États, a été cité comme le fondement juridique des pavillons de complaisance actuels. Cet article remet en question cette décision dans son contexte historique, mettant en valeur les problèmes spécifiques contestés et le rôle de l'arbitre américain, le juge en chef Melville Fuller, dans la résolution de l'affaire.

In 1905, the Permanent Court of Arbitration in The Hague, Netherlands, issued its fourth arbitral award: the Muscat Dhows decision. This decision has been regularly cited in the legal literature surrounding the later practice of issuing flags of convenience to merchant ships. ${ }^{1}$ The decision stated: "generally speaking it belongs to every Sovereign to decide to who he will accord the right to fly his flag and to prescribe the rules governing such grants." 2 The language of this case has been cited many times; it forms the basis of international law for the later practice that continues today of registry

1 The case has been cited many times, both in traditional print sources and on the Internet in discussions related to flags of convenience. The citations in journals of international law consistently mention the significance of the decision without presenting the historical context. See: S. McDougal, William T. Burke and Ivan A. Vlasic, "The Maintenance of Public Order at Sea and the Nationality of Ships," The American Journal of International Law vol. 54, no. 1 (Jan. 1960), 57 n 68. Historians mention the decision as well: Elizabeth R. DeSombre, in her excellent study of port state control as a means of offsetting some of the negative effects of flags of convenience also notes the decision: Flagging Standards: Globalization, Environmental Safety, and Labor Relations at Sea (Cambridge, MA: MIT Press, 2006). Recent internet publications include: http://www.law.kuleuven.be /iir/nl/onderzoek/opinies/dipl.pdf.

2 The final text of the decision is in James Brown Scott, Hague Court Reports, Comprising the Awards; Volume 1 (1916), available online via Google e-books, or on line at: http://archive.org/details/haguecourtreport028086mbp). Hereafter Scott, Hague Court Reports. The quoted phrase appears on p. 95.

The Northern Mariner/Le marin du nord XXIV, No. 1 (January 2014), 23-40 
of ships under flags of convenience, ranging from Panama and Liberia to those of Vanuatu and the Marshall Islands. None of the legal treatises and other works referring to the Muscat Dhows case, however, make any effort to describe the background of the case or to place the case in its various historical contexts. In the century since the decision, national states have lost control not only over merchant shipping, but over corporate operations and banking activities that have sought offshore havens. The 1905 Muscat Dhows decision, originally bearing on a local situation in a remote corner of the Indian Ocean, lies at the root of these crucial modern developments.

This article addresses the historical circumstances of the case and seeks to develop an historical, not just a legal, understanding of the decision. British-French imperial rivalry in the late nineteenth century, the Indian Ocean slave trade, and the AngloFrench rapprochement known as the "Entente Cordiale" of 1904 formed the backdrop to the case. So too did the

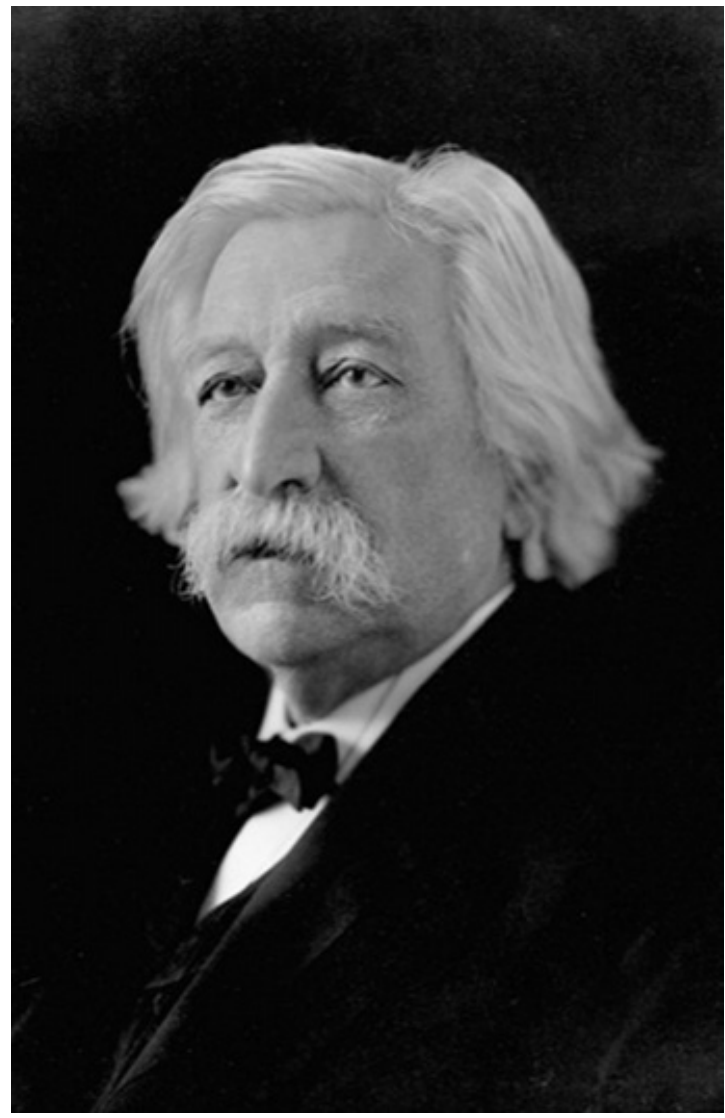

Melville Weston Fuller (1833-1910), eighth Chief Justice of the United States.

evolution of the concept of international law, and the development of the practice of international arbitration. More particular influences were the establishment of the Hague Permanent Court of Arbitration where the case was heard, and the role of Chief Justice Melville Fuller, the American arbiter.

\section{Imperial Rivalry Context}

In the "scramble for Africa" European countries competed to colonize the continent, while they also solidified their colonial control of remote islands and mainland territories in Asia and across virtually every ocean. In Africa, Spain maintained small enclaves and colonies. Portugal held two large colonies in the southern part of the content (Angola and Mozambique). Germany established claims in the Cameroons, South West Africa (present-day Namibia), and what is now mainland Tanzania, while Italy exercised protectorates in the Horn of Africa. The British sought to establish a string of holdings from Cairo to Capetown, including colonies, protectorates, and areas of influence, while the French maintained colonies in West Africa, and on the islands of the Indian Ocean. As early as the 1840s, entrepreneurial British shipowner William Schaw 
Lindsay established a profitable route to carry passengers and mail to Asia via Africa and India. He built at his own expense several coaling stations along the route and acquired a nucleus of passenger liners. Additionally, he chartered sailing ships that carried coal to be consumed by his steamers, and upon returning from the East they were loaded with African and Indian produce. ${ }^{3}$

Although the Suez Canal had been constructed by the French under the engineer Ferdinand de Lesseps in 1869, the shortcut to the East passed under British control by the cession by the Khedive of Egypt to Britain of the military protection of the canal in 1878 . In the following years, the French sought to establish a route up the Congo River and across the Sudan and Ethiopia to a small holding (Obokh, later known by the name of the larger city, Djibouti) on the Red Sea, where it joins the Indian Ocean. The French plan for an East-West route across Africa and the British plan for a North-South string of colonies clashed at Fashoda, Sudan in 1898, where the French plan was foiled.

France had also established a string of colonies around the world, most of which were between the Equator and the Tropic of Cancer. French Indo-China was formed in 1887, including Tonkin, Annam, Cochin China and Cambodia, and eventually became one of the richest French possessions. However, for French coal-fired warships to reach Indo-China from France, they had to proceed around Africa and through the Indian Ocean. The route around South America and across the Pacific was impractical, and far too long, with very few French-controlled ports along the way.

By 1890, the French had established colonies and coaling stations in West Africa, in India (Pondicherry and Karaikal) on the eastern side of the sub-continent, in the Indian Ocean on Madagascar, the Comoros, and the Seychelles, and at Obokh or Djibouti, the little outpost at the mouth of the Red Sea. However, from Obokh to Pondicherry or Karaikal was an intimidating 2,900 nautical miles or more, nearing the outer limit of the cruising range of the latest French warships of the 1890s. ${ }^{4}$ The best spot for a coaling station was the self-governed Arab sultanate of Oman, also known, then, by the name of its capital, "Muscat," and shown on maps of the era as "Muscat and Oman," at the northeast tip of the Arabian peninsula. It was almost exactly 1,500 nautical miles from either Obokh to the west and Karaikal or Pondicherry on the east.

The British, of course, had numerous colonies and ports around Africa and across the Indian Ocean. By the 1890s, their holdings with seaports in Africa included Sierra Leone, the Gold Coast (today, Ghana), Nigeria, South Africa (Cape Colony and Natal), Zanzibar, British East Africa (today, Kenya) and British Somaliland at the mouth of the Red Sea. On the Arabian Peninsula, Britain held a small enclave at Aden. In the Indian Ocean, Britain had numerous ports and coaling stations in what are now the nations of Pakistan, India, Sri Lanka, and Bangladesh, that stood in the way of French passage from Obokh to Pondicherry.

3 Michael Clark, "William Schaw Lindsay: Righting the Wrongs of a Radical Shipowner," The Northern Mariner/Le marin du nord vol. XX, no.3 (July 2010), 283-311.

4 Depending on the exact sailing route, the trip could have been much longer, especially if cruising relatively close to the coasts of what are now Iran, Pakistan, and India, rather than taking a more direct mid-ocean route from Djibouti to the southern tip of Sri Lanka. 
By the 1860s, Britain had also established an informal protectorate over Muscat and Oman at the mouth of the Persian Gulf, and had succeeded in severing control of Zanzibar from the Omani sultan in 1861. In 1890 the British formally established Zanzibar as a protectorate with a separate sultan.

In 1898, the same year as the British and French schemes for land routes through Africa clashed at Fashoda, French efforts to establish a coaling station in the de facto British protectorate of Oman set off a less-known maritime dispute that would simmer for some years.

\section{Indian Ocean Slave Trade Context}

The Atlantic slave trade was almost entirely eliminated by the late 1860 s, but the Indian Ocean slave trade continued to thrive throughout the last decades of the nineteenth century and well into the twentieth century. Slave traders operated from Zanzibar and nearby regions and exported slaves by Arab dhows to the Arabian Peninsula, to the small states of the Persian Gulf, and to India. Dhows built in and operated from the city of Sür on the northeastern coast of Oman engaged in this trade. The British led in the effort to suppress the Eastern or Indian Ocean slave trade, as they had led the suppression of the Atlantic slave trade. Observers in both continental Europe and the United States, however, saw the British anti-slavery operations as not entirely motivated by the injustice of human bondage, but rather as tool in British efforts to dominate both Africa and the high seas.

Because the Omani state was nominally independent and only under informal British protection, the French were able to declare certain individual Omanis to be "protégés," which implied they enjoyed a certain degree of French protection. Protégé status had been a means by which France had extended influence over parts of North West Africa, especially Morocco, as a step towards establishing colonial control there. Native peoples claiming French protection were found throughout the Ottoman Empire and in independent Moslem states. Numerous dhow owners, as French protégés, had the right to fly the French maritime flag from their vessels. In Britain, contemporary writers were quite convinced that the French willingly consented to the use of the French flag to shelter the slave trade carried on by the dhows of Oman. British publicists uncritically accepted assertions that the slave trade flourished on a large scale under such protection, in part in an effort to discredit the French. A closer look at the evidence suggests that at least some of the dhows engaged in the Indian slave trade were in fact operated by French protégés under the French flag. In short, although the British response was couched in moral indignation and some may have exaggerated the scale of the practice, their claims were to some degree substantiated. ${ }^{5}$

$5 \quad$ H.J. Whigham, The Persian Problem: An Examination of the Rival Positions of Russia and Great Britain in Persia with Some Account of the Persian Gulf (London: Isbistor, 1903), 21. George Lydiard Sulivan, Dhow chasing in Zanzibar waters and on the eastern coast of Africa. Narrative of five years' experiences in the suppression of the slave trade (London: S. Low, Marston, Low \& Searle, 1873). Available online at http://archive.org/details/ dhowchasinginzan00sulirich. Modern research substantiates the British claim of extensive 
In 1889, eleven European powers, as well as Turkey and the Congo "Free State" (actually a personal colony of the King of Belgium) met at a conference in Brussels, Belgium, to discuss the suppression of the Indian Ocean slave trade. The result was an international convention, signed by the thirteen countries, known as the "General Act of the Brussels Conference Relative to the African Slave Trade, signed at Brussels, July 2, 1890."6 Britain acceded to the convention in 1892 . The convention recognized an established practice of granting the use of the maritime flag of the European powers to local boats and ships owned by nonEuropean peoples regarded as "protégés.", Under the convention the French undertook to ensure that French flagged native-owned vessels did not transport slaves, and the British pledged to prevent ships under their flag from engaging in the trade. The convention

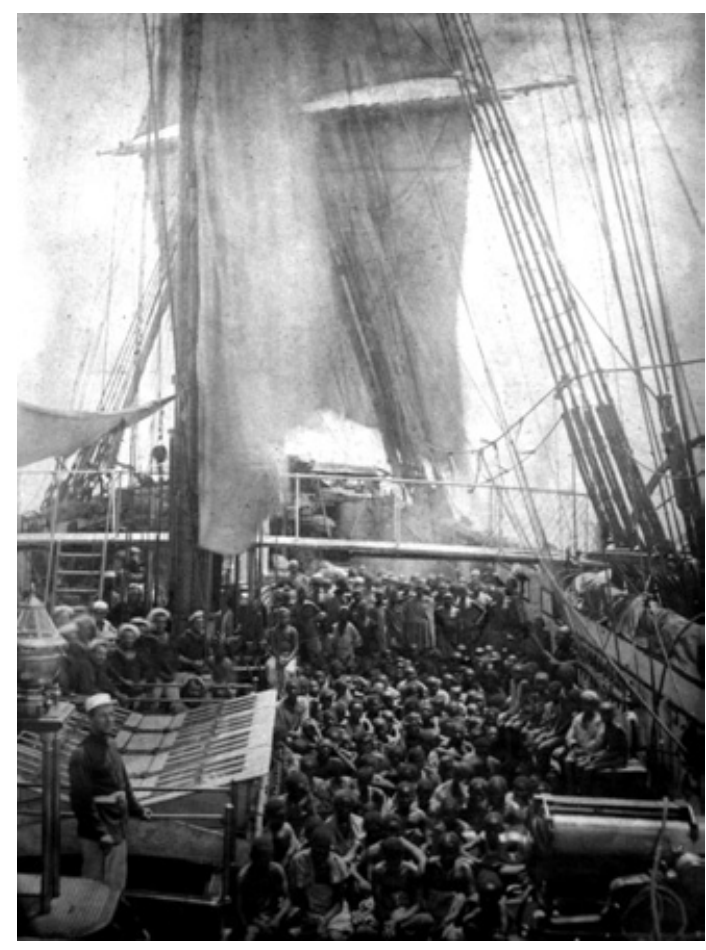

Slaves rescued from a dhow aboard HMS Daphne, 1868.

\section{also declared that European powers} could only extend such a right of flag use to protégés who could demonstrate that their protected status predated the signing of the convention. ${ }^{8}$ The states participating in the

slave trade in dhows out of Oman: Janet Ewald, "Crossers of the Sea: Slaves, Freedmen, and Other Migrants in the Northwestern Indian Ocean, c. 1750-1914," The American Historical Review vol. 105, no. 1 (February 2000), 69-91; also: Georges Malecot, "Quelques aspects de la vie maritime en mer Rouge dans la première moitié du XIXe siècle," L'Afrique et l'Asie modernes 164 (1990), 31.

6 The original conference members and signatories were Great Britain, Germany, Belgium, Spain, the Congo, France, Italy, the Netherlands, Portugal, Sweden, Norway and Turkey. In 1900, Austria-Hungary, the United States, Liberia, and Persia (Iran) also signed. British Foreign Office records demonstrate that slave trade aboard French-flagged dhows did in fact flourish in the mid- and late 1890s. Kew, The National Archives, FO 27/3489, contains many such on-the-spot reports.

7 Great Britain, Muscat Dhows Arbitration. In the Permanent Court of Arbitration at The Hague. Grant of the French Flag to Muscat Dhows. The Case on behalf of the Government of His Britannic Majesty... (London: Foreign Office, 1905), 40-53, http://babel.hathitrust.org /cgi/pt?id=coo.31924007461209; view=1up;seq=1.

8 Acceded to in January 1892; see especially articles XXX-XXXV dealing with granting of flag. The General Act of the Brussels Conference, is available on line: http://babel.hathitrust.org/cgi/pt?id=mdp.35112104560067;seq=50;view=1up;num=48. 
convention were not henceforth to grant such protection.

The British understood that if a slave-trading dhow flew the French flag, the Royal Navy would not be able to exercise the right of search on such ships. Frenchflagged ships were immune from the British anti-slavery patrols because, in their accession to the Quintuple Treaty in 1845, the French had explicitly denied the right of search during peacetime. ${ }^{9}$ It was up to the French to police the ships carrying their own flag.

Although the British emphasized misuse of the French flag to shelter slavetrading dhows, there was a less-high minded concern that the continued extension of protégé status to individuals was a lever for the expansion of French influence and power. From the British point of view, the French were insidiously inserting themselves into Muscat and Oman through the hundreds of Omanis claiming French protection. Since the crews of the ships and the families of the French-flagged dhow owners all claimed some degree of French protection, the number of individuals easily exceeded a thousand. Thus the British were eager to see the terms of the Brussels Act enforced, with the French obliged to prevent slave-trading on French-flagged dhows, and to terminate the granting of protégé status.

Soon after the convention was signed by both Britain and France, British resident agents and officers aboard the anti-slavery patrols of the Royal Navy in the Indian Ocean reported numerous slaves being shipped to the Persian Gulf in dhows that flew the French flag. The reports suggested that Sür-based dhows under the French flag carried as many as thirty-three or more slaves per voyage. ${ }^{10}$

Considering the size of the dhow fleet and the carrying capacity of the vessels, the trade may have been very much larger. One report showed that there were fifty-six dhows from Sür that claimed the French flag. Since the larger dhows could carry as many as 200 to 300 or more slaves, as few as three or four of the dhows, or just two or three annual trips by one or two of the dhows, could have accounted for some 1,000 slaves per year. The trip only took a few weeks. ${ }^{11}$

The basis for French protégé status varied. A number of the Sür dhow owners based their claim on the fact that they or their families owned real estate in the French

9 Scott, Hague Court Reports, 94. Under this international treaty the signatory powers agreed to cooperate in the suppression of the slave trade, allowing each other to inspect ships flying any of the signatory's flags. The United States was not a party to this treaty. Although the French signed the Quintuple treaty in 1841 , they abrogated the search convention in 1845 , and the British went along, as explained, p.516 in Howard Hazen Wilson, "Some Principal Aspects of the British Efforts to Crush the African Slave Trade, 1808-1929," American Journal of International Law vol. 44, no.3 (July 1950), 505-526.

10 Lt. Col. Talbot to Chief Ras-ul Khaimah, 7 August 1892, Great Britain, Muscat Dhows Arbitration. In the Permanent Court of Arbitration at The Hague. Grant of the French Flag to Muscat Dhows. The Counter-case on behalf of the Government of His Britannic Majesty (London: Foreign Office, 1905), Appendix (App.) 7, p.48, http://babel.hathitrust.org/cgi/pt? $\mathrm{id}=$ coo.31924007461217; view=1 up;seq=5. Hereafter British Counter-case

11 The owners of the fifty-six dhows, British Counter-case, App. 12, p. 56. 


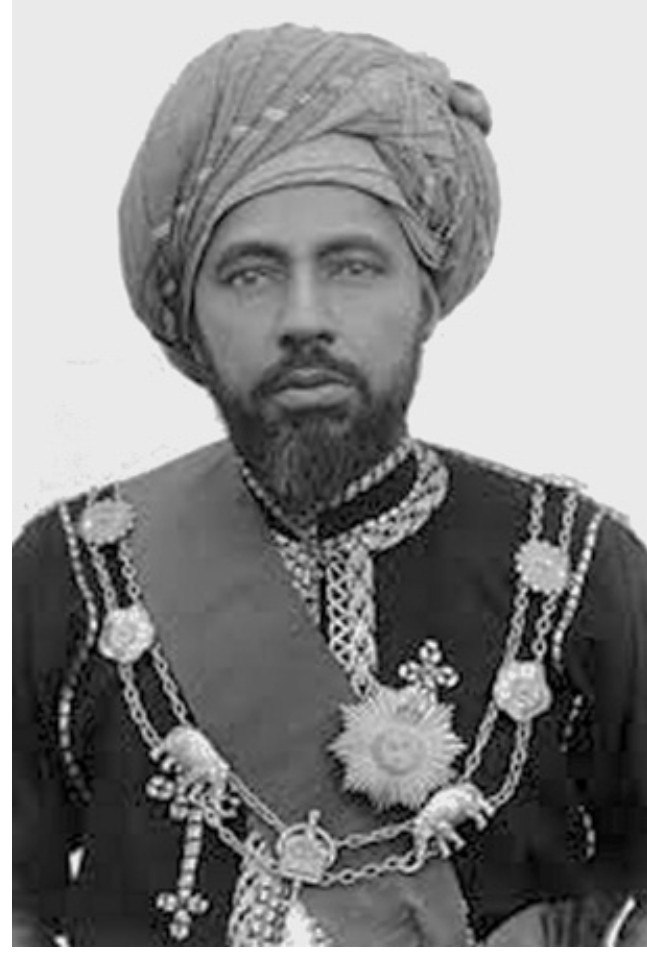

Sayyid Faisal bin Turki, (1864 - 1913).

enclave of Obokh. Others simply reported that their parents or other family members had protégé status and that it devolved upon them as well ${ }^{12}$ Others were not entirely sure how they had obtained the status.

\section{Omani Political and Diplomatic Context}

In 1888, Faisal ibn Turki took power as sultan in Oman's capital, Muscat. Political conditions in Oman were extremely unstable through the early 1890 s, as the sultan typically did not exercise control beyond the capital. Even in the capital his rule was tenuous; when a local tribe attacked the city in 1895 , the sultan had to to pay a ransom to the raiders to retrieve control. ${ }^{13}$ The sultan briefly took refuge in the Jalali Fort, high over the port of Muscat, and his supporters claimed that the British frustrated his efforts to regain control, compelling him to court French support. Later in 1895, he formally offered to the French the right to establish a coaling station at a port near Muscat, Bandar Jissah. ${ }^{14}$ In May 1897, the captain of HMS Blonde reported that thirty-eight dhows had registered through the French Consul at Zanzibar. ${ }^{15}$ The French informed the British that they did not intend to stop the practice of issuing French flags to dhows in the Indian Ocean. ${ }^{16}$

On 10 July 1898, the crisis at Fashoda in the Sudan came to a head, bringing France and Britain to the brink of war. British General Herbert Kitchener arrived from Egypt with a force of troops that far outnumbered the small French expedition that come overland from the Congo region. The collapse of the French trans-Africa plans came at almost exactly the same time that the French were working to establish the coaling station in Oman.

In early 1899 , the British terminated their cash subsidy to the Sultan of Oman on

12 The British believed that many claiming French status did so fraudulently. British Claim, 14-15.

13 Roby C. Barrett, Oman:The Present in the Context of a Fractured Past Joint Special Operations University Report 11-5 (MacDill Air Force Base, FL: JSOU Press, 2011), p. 96, http://jsou.socom.milo/JSO\%20publication/11-5_Oman_final.pdf.

$14 \mathrm{http} / /$ www.globalsecurity.org/military/world/gulf/oman-faisal.htm. This version of events is supported by New York Times 7 and 8 March 1899; the fort at Jalali is a regular tourist stop today and accounts of the sultan taking refuge there are part of the guides' narration.

15 British Claim, 14.

16 Ibid. 
the grounds that the sultan had improperly agreed to let the French establish a coaling station. ${ }^{17}$ That particular issue was resolved on 27 February 1899 with the French ambassador to Oman stating that the French were willing to accept a "coal depot" on the same terms that the British had a coal depot or wharf, and next to the existing British wharf. The coaling depot would be granted "on sufferance," and not with any special or permanent rights such as at the larger outpost at Pondicherry in India or the Obokh enclave on the Horn of Africa. ${ }^{18}$

Observers around the world tied the resolution of the Muscat coaling station issue to the simultaneous resolution of the Fashoda crisis. However, reports also indicated that the only reason the sultan backed down from his agreement to grant a full-fledged coaling station was that he was forced to board the British flagship in the harbor under threat that his palace would be bombarded if he did not do so. ${ }^{19}$ The sultan, realizing his independence had been virtually destroyed and that he was in effect subject to British control, resigned. However, Lord Curzon, the viceroy of India, rejected the resignation. The sultan simply retired from active administration, leaving affairs of state to two deputies. $^{20}$

Henceforth, it was clear the sultan and his deputies continued to act on British orders. In 1903, for example, after an incident in a tribal dispute in which a French flag was fired on in Sür, the sultan took no action. In April 1903, when five residents of Sür broke quarantine, they were arrested. They claimed that they were French protégés and not subject to arrest by the sultan's officers. The sultan ignored this claim. These instances of the sultan's government refusing to extend special protection to the French were later cited by the British to demonstrate that the protégé status had no real standing. ${ }^{21}$

The testimony of individual Omanis about their status did not live up to the precise nature of European thinking, and from the British viewpoint was so obscure and disorganized as to be meaningless. The British quoted from the statement of one of the quarantine-breakers, Khalfan-bin-Muhammed:

Khalfan states: "I am a French subject, having flown the French flag for five or six years. I got it at Jibuti, where I own a house. There is no one belonging to me residing in it." Subsequently he says: "I cannot exactly explain what grounds I have for believing that we are all French protégés. My cousin Juma knows most about it,

17 The Sydney Morning Herald, 15 February 1899.

18 Marquis of Salisbury to Sir E. Monson, 27 February 1899, British Counter-case, App. 14, p. 56. A full discussion of the coaling station dispute and its final resolution can be found in Y.A. al-ghailani, "Oman and the Franco-British Colonial Rivalry: The Bandar al-Jissah Crisis, 1898-1900," Adab Journal University of Khartoum no. 27 (2009) available online at http://adabjournal.uofk.edu/current\%20issue/ISSUES\%20ENGLISH/Dr.\%20Y.A.\%20alghailani.pdf

19 New York Times, 7 and 8 March 1899; Hussein Ghubash, Oman Islamic Democratic Tradition (London: Routledge, 2006), 149-150.

20 Ibid.

21 British Claim, 18. 
and he says so. I made a mistake in stating that I share the ownership of a house in Jibuti ; it belongs really to my cousin Juma entirely, but we are a united family, and look upon it as a family concern. Juma and I were both born and bred in Sür; neither of us nor any of our family have ever lived in Jibuti. As to the house, I have never lived in it, and I cannot say I have seen it. Juma has not been to sea for four or five years." 22

\section{The Entente Cordiale context}

The British continued to protest that the continued French grant of flags to the owners of dhows in Oman violated the terms of the convention, but the French continued to claim that they had the right to issue the flag to any party they chose. The British and French, however, were moving towards a resolution of their competing colonial claims in Niger, Newfoundland, railroad routes in Ethiopia, jurisdiction in the New Hebrides and elsewhere concluded in the "Entente Cordiale" signed in April 1904. ${ }^{23}$

As part of the resolution of colonial difficulties, the British and French agreed, on 13 October 1904, to submit the Muscat Dhows dispute to the newly formed Hague Permanent Court of Arbitration. ${ }^{24}$ The arbitration proceeded smoothly and was readily accepted by both sides. This context broaches an important question: why did the French and British not simply fold the easy resolution of the Muscat Dhows dispute into the multiple clauses of the Entente Cordiale of April 1904 rather than submitting it to the Hague, and resolving it a year later?

\section{The Hague Permanent Court of Arbitration}

Established in 1899, The Hague Permanent Court of Arbitration (PCA) provided a mechanism by which nations could submit disputes for arbitration by independent jurists. Sovereign nations would nominate experts in international law to sit as a "permanent" panel, from among whom jurists or other prominent authorities could be chosen for a small panel to hear both sides of a specific case and then issue a decision. Both sides would agree in advance to abide by the decision. Each would appoint one (nominally neutral) arbiter from among the permanent group of international jurists, and those two in turn would select a third from the list of panelists who would serve as "umpire." If the two could not decide on a third party, the Permanent Court would select an outside party (the King of Italy, for example) to nominate the umpire. In effect, The Hague "Court" simply provided a formal structure for the long-standing practice of arbitration of international disputes. It varied from earlier arbitration agreements because there was a permanent body of highly-respected jurists or legal authorities from whom to select the small decision-

22 British Counter-case, 16-17.

23 P. J. V. Rolo, Entente Cordiale: the origins and negotiation of the Anglo-French agreements of 8 April 1904 (London,1969).

24 Scott, Hague Court Reports, 93, 102. The agreement to arbitrate was published in the United States: "Great Britain v. France," The American Journal of International Law vol. 2, no. 4 (October 1908), 921-928. 


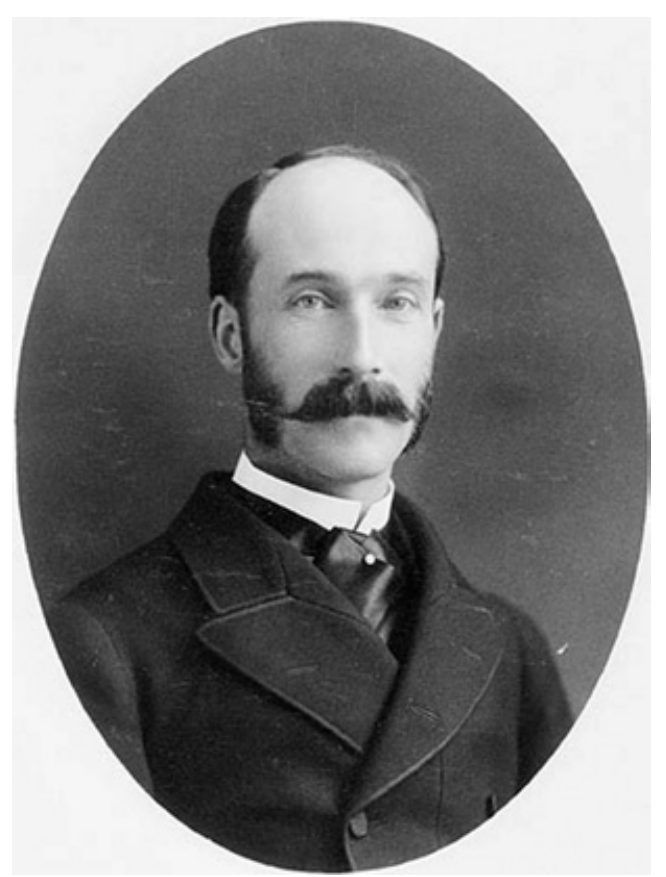

Henry Petty-Fitzmaurice, 5th Marquess of Lansdowne (1845-1927).

making panels; but the term "court" was a bit misleading as the "cases" led to arbitral awards, not judgements.

The Dhow case was only the fourth brought to The Hague. Previous cases were the dispute between Mexico and the United States concerning funds owing to the Roman Catholic church for missions in California, the combined British and German naval blockade of Venezuela in 1902-3 over the repayments of debts to their nationals, and the Japanese house tax as applied to foreign residents. The Muscat Dhows case, therefore, was the first the PCA arbitrated between major European powers.

Prior to the assembly of the arbiters, on 25 March 1905 the French submitted to the sultan the names of the dhow owners to whom they had issued the flag. Acting under British orders, the sultan replied that he could not recognize that the French flag had any jurisdiction over his subjects whatsoever, and referred the whole matter to the upcoming Hague tribunal decision. ${ }^{25}$

The French objected to the inclusion of the Sultan of Oman as a party to the arbitration. ${ }^{26}$ British Foreign Minister, the Marquess of Lansdowne, replied that the sultan had asked to be represented by the British, and not under pressure as the French asserted. Nevertheless, Lansdowne added that the British Government "do not however regard it as essential that the name of his Highness should appear as one of the plaintiffs in the suit, and they will in deference to the views of the French Government omit it in further documents to be presented to the Court at the Hague." 27 Not surprisingly, in view of the British insistence they represented the sultan, the published version of the British arguments was entitled: Muscat Dhows Arbitration. In the Permanent Court of Arbitration at the Hague. Grant of the French Flag to Muscat Dhows. The Case on Behalf of the Government of His Britannic Majesty and of His Highness the Sultan of Muscat.

British Counter-case, App. 12, pp. 55-56. There were twenty-six owners, with a total of fifty-six dhows, crewed by about 1,060 men.

26 Cambon to Lansdowne, 6 February 1905 in Melville Fuller papers, Muscat Dhows Arbitration 1904-05 folder, Box 13, Manuscript Division, Library of Congress. Hereafter Fuller Papers.

27 Lansdowne to Cambon, 15 March 1905, ibid. 


\section{The Arbiters and the Award}

Under the rules of the PCA, each of the two parties could nominate an arbiter, not from their own country, from a list of all the arbiter panel appointed to the PCA by all the signatory nations. In 1905, the potential pool of arbiters numbered about forty (the number varied as members died; most signatory nations nominated between two and four individuals to the pool, although a few failed to

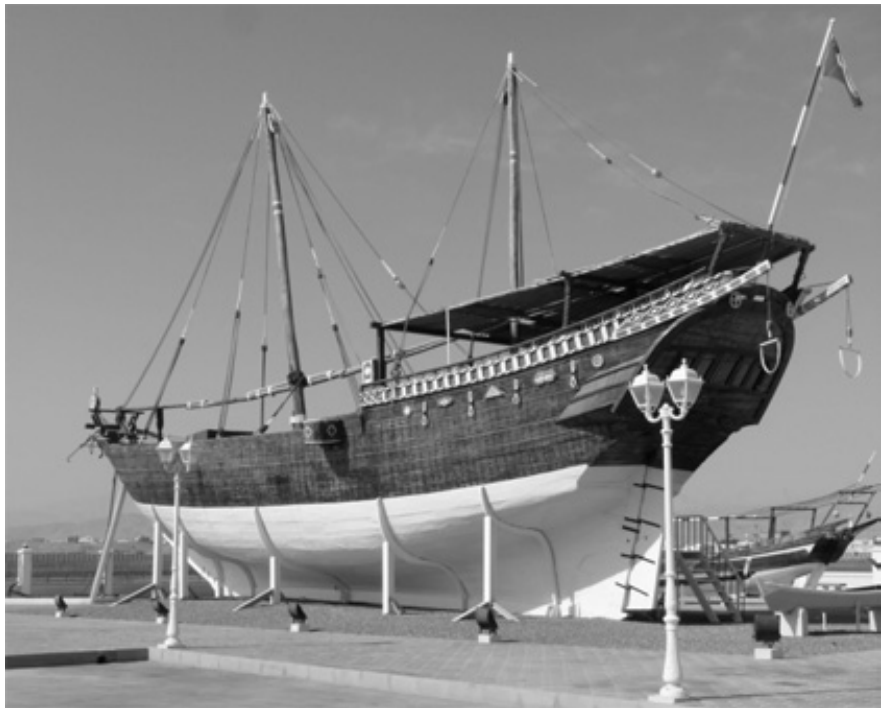

Replica Sür dhow on display. nominate any). Procedure also called for the two panelists to agree within a month on a third panelist who would serve as "umpire." If they failed within a month, the governing body of the PCA would decide on an independent party to name the umpire.

The arbiters for the Dhows case were H. Lammasch, a member of the Austrian Parliament who had served on the Venezuelan case, and acted as umpire; Melville Fuller, chief justice of the U.S. Supreme Court; and Alexander de Savornin Lohman, a Dutch aristocrat and respected professor of law, who had served on the "pious fund" case dealing with the California missions. Fuller had been chosen by Britain and de Savonin Lohman by France. ${ }^{28}$ Fuller remained a member of the panel of the court, and served later on a decision regarding German deserters in French Morocco.

Although the members of the arbitration panel were supposed to be impartial, Fuller believed that his selection by the British meant that he would represent their interests. Evidence surfaced even before the proceedings began on 25 July 1905, and can be found in his personal papers now in the Library of Congress Manuscript Collection.

In February 1905, Fuller and Lohman, the arbiter chosen by the French, exchanged cables in which they sought to agree on the umpire. "The British quietly suggested to Fuller that it would be important to name an arbiter who spoke English. The British ambassador to the United States, H.M. Durand, wrote to Fuller on 17 February 1905, stating "it would look better if the selection of an Umpire could be made by the

28 http://www.haguejusticeportal.net./index.php?id=6926 Fuller had earlier served on the Venezuelan-British Guiana border arbitration as an arbiter in 1897, which had produced a decision favorable to Britain. Even though he had been selected by Venezuela as one of their choices on the panel, he had proved himself acceptable to the British point of view. He continued to serve on the Hague Permanent Court until his death in 1910. See: http://www.historycentral.com/Bio/rec/MelvilleFuller.html 
Arbitrators by the date specified. Either Count [Constantine] Nigra or Monsieur Gram, on account of their knowledge of English would be very well fitted to act, but His Majesty's Government add that they will be content with any choice that may recommend itself to you." 29 "Nigra" was Count Constantine Nigra of Italy, the former ambassador of Italy to Great Britain, while "Gram" was Gregor Gram, the former prime minister of Norway (1889-1891 and 1893-1898), and was currently serving as governor of a Norwegian province.

Fuller, three days after Durand sent the note with Britain's wishes, wired Lohman, stating "In compliment to the King of Italy, who chooses if we fail, I suggest that we select Count Nigra." Fuller did not mention to Lohman that the name had been suggested to him by the British ambassador to the United States. Count Nigra apparently declined, so on 23 February Fuller sent a cable to Jonkheer L.H. Ruyssenaers, secretary general of the PCA, "I propose Gram Consider knowledge of English of vital importance." Again, Fuller made no mention that the name had been suggested to him through the British Embassy, stressing only the English language fluency as his reason for selection. ${ }^{30}$

As it turned out, Fuller and Lohman did not decide on the umpire within the required time limit of one month. Ruyssenaers explained to Fuller that his own PCA colleagues thought it proper to give the choice to the King of Italy, who in turn, nominated Lammasch, who accepted the post. ${ }^{31}$

While there was nothing improper in Fuller's forwarding of the British suggestions over his own name, the episode demonstrated Fuller's propensity to perceive himself as representing Britain, rather than acting as a fully independent jurist. In fact, when Fuller had been selected as chief justice of the United States Supreme Court in 1888 , the press had remarked on the fact that Fuller, unlike most Supreme Court nominees, had a strong prior career "at the bar" and not "on the bench"- that is, he had never served as a judge, but always as an attorney representing one or another side in legal disputes. ${ }^{32}$

At the PCA, the three arbiters rendered their decision on 5 August 1905, after reviewing the documents submitted by the British and French and hearing further arguments. In light of the British concern that the panelists be fluent in English, it is interesting to note that the agent of the French, Maurice Herbette, who presented the French side, notified Ruyssenaers (in French) that he would like the presence of an interpreter during the British oral arguments because of his own imperfect command of English. Ruyssenaers replied that it would not be necessary, since the transcript would be

2917 February 1905, Fuller Papers.

3023 February 1905, cable draft Fuller to Ruyssenaers, ibid.

31 Ruysennaers to Miller, 25 February 1905, ibid.

32 Numerous press reports in the period May 1888-July 1888 remarked on Fuller's background as an attorney, rather than a judge. See "Melville Fuller," American Law Review (May/June 1888), 448ff. 
produced in both languages. ${ }^{33}$

Melville Fuller took a very active role. From a close review of his notes from the arbitration, it is clear that he went over a carbon copy draft of the decision, and later, printed page proofs, carefully clarifying details and correcting errors of style. One of the most significant changes he introduced was in the key passage later cited in defense of the principle of flags of convenience, and a passage that was entirely satisfactory from the British viewpoint: "Whereas generally speaking it belongs to every Sovereign to decide to whom he will accord the right to fly his flag and to prescribe the rules governing such grants..." Fuller twice, once in the transcript and then in the page proofs, insisted on the insertion of the phrase "generally speaking." 34

With this addition, Fuller made it clear that the right of a nation to allow people in other countries to fly its flag was a principle in existing international law. At the same time he wanted to make it clear that, although the principle was general, it was limited in particular cases, such as the Muscat Dhow situation, by existing treaties and agreements. The phrase helped clarify that, in this situation, the general principle did not quite apply because of treaties.

Britain itself made a practice of permitting use of the red ensign, its merchant marine flag, by British subjects in Canada and elsewhere in the Empire, and also by foreigners who incorporated a firm in Britain. In short, the British wanted to deny the French protégé claim but at the same time preserve the principle that a nation could issue its maritime flag to non-nationals. Thus the phrase "Whereas generally speaking" that Fuller insisted on inserting, was exactly in line with the British position.

The arbiters' award in the Dhows case was often referred to in later years as a "Hague" decision or "Hague ruling," as if the arbitration award were in fact a court decision on a matter of international law, requiring adherence by other countries. While it did acquire that status in practice, the decision was no such thing when it was rendered, but simply an award in a particular case by three specially selected jurists, presumed to be impartial.

The award held that any country could grant its maritime flag to anyone, subject only to treaties or agreements limiting that right. In this specific case, the arbiters concluded that the right of France to grant her maritime flag to native vessels was limited by the 1890 Act of Brussels. That convention specifically stated that the

33 Herbette to Ruyssenaers, 25 July 1905 and Ruyssenaer to Herbette, 1 August 1905, Fuller Papers. Ruyssenaers was "Secretary General" of the PCA, under Article 28 of the 1899 PCA agreement, by virtue of being a Netherlands minister of state. He was supported by a Permanent Administrative Council, made up of the representatives of the signatory powers accredited to the Netherlands.

34 Undated typed carbon copy of the draft decision, edited in Fuller's own hand, Box 13, Muscat Dhows folder, Fuller Papers; the printed page proofs are in the Permanent Court of Arbitration folder, ibid. In the printed page proof version, Fuller corrects the typo on page 2 of the proofs "generally spoke" to "generally speaking," again in his handwriting. 
signatory parties agreed that they would not grant their flag to "protégés" who had received that status after $1890 .^{35}$

The arbiters stated that the French were correct in claiming that, in general, they had the right to issue their flag to anyone they chose, subject only to their own internal laws and decisions. A British claim that the French had violated their own domestic law was ignored; the implication by the arbiters was that if the French government chose to take an action contrary to their own domestic law, no other country or authority had a right to overrule such a decision. At the same time, the granting of the flag did not impair the sovereign rights of the sultan. The specific language read: "Whereas, generally speaking, every sovereign may decide to whom it will accord the "right to fly its flag and to prescribe the rules governing its use, and the granting of the right to subjects of another sovereign constitutes no attack upon the latter's independence..." 36

The arbiters made it clear that only a very few dhows, and probably none, had a right to fly the French flag. To be entitled under the Brussels Act, the dhows would have to be the same dhows owned by the same individuals who had been already been granted the status of French protégé as of 1890. After the passage of fifteen years, changes of ownership, and thin or non-existent documentation left very few, if any, dhows legitimately under the French flag in 1905. With the sultan's government siding with the British in such disputes, and with the French conceding this practical point, Omani dhow owners were no longer in a position to use the French flag to prevent inspection by the ships of the British Indian Ocean anti-slavery squadron. The French, having accepted the Hague Muscat Dhows decision, would not come to the assistance of any dhow owner making such a claim of wrongful exercise of the right of search. Furthermore, French influence in the British de facto protectorate of Oman would not be extended by the granting of new protégé status.

\section{The context of the growth of "International Law" as a concept}

This dispute in a corner of the world unfamiliar to most Americans and to most Europeans, and its resolution by the arbiters at the Hague, provided a precedent for future years justifying the action of ship-owners seeking to protect ships from the vicissitudes of war, labor legislation, embargoes, immigration restrictions, environmental regulation or tax policies, by registering a ship in a foreign country. As later interpreters would put it, the Hague Court had ruled that any sovereign country could issue its merchant flag to anyone it chose, bound only by treaties or by its own practices, which could not be challenged abroad. The twentieth century "legal justification" for flags of convenience had been firmly established. ${ }^{37}$

35 Scott, Hague Court Reports, $93 \mathrm{ff}$.

36 Ibid.

37 See ibid., 93-109; Boleslaw Adam Boczek Flags of Convenience: An International Legal Study (Cambridge, MA: Harvard University Press, 1962). 

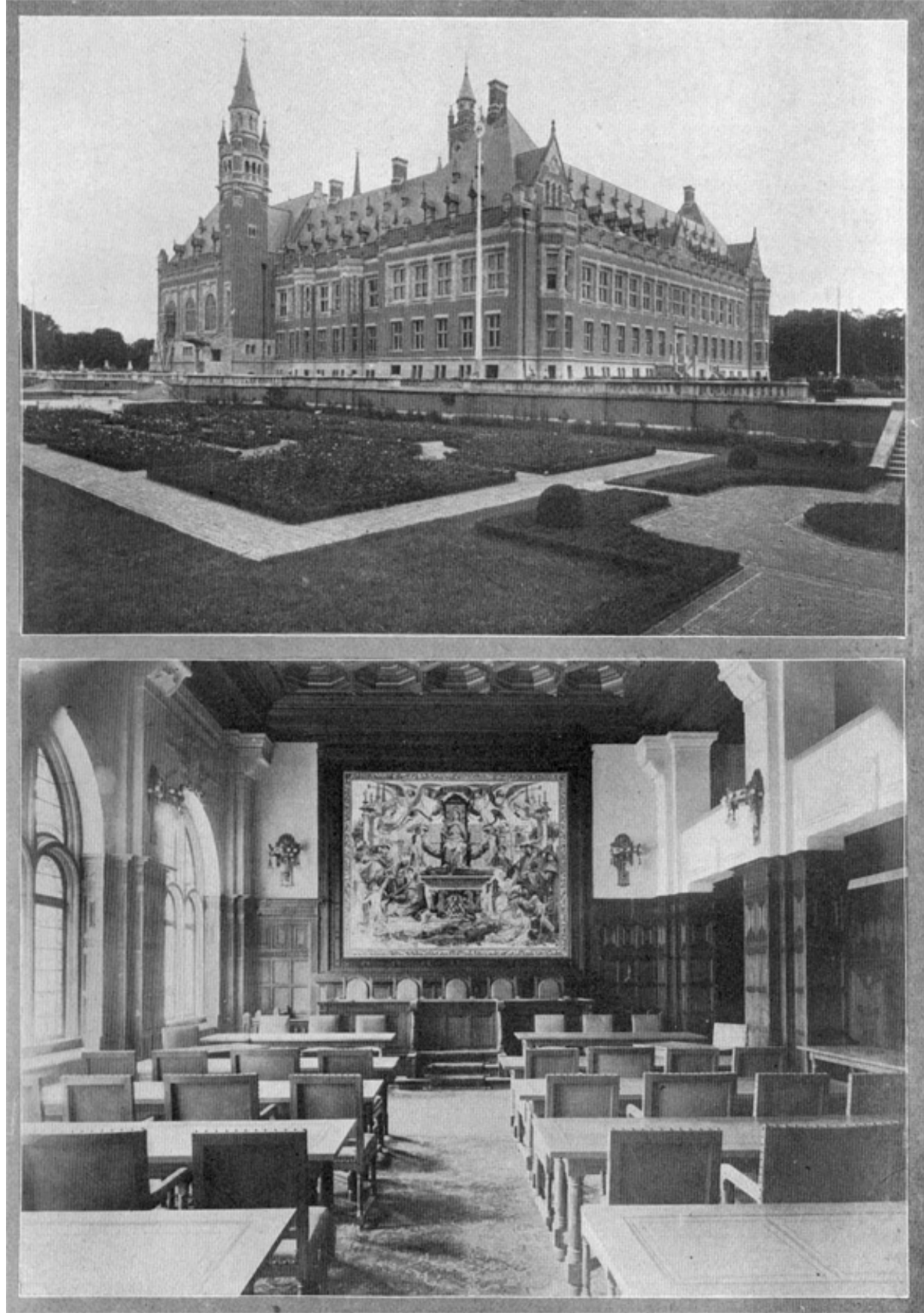

The Hague, Palace of Peace established as a "Court of Arbitration with Permanent Council and Bureau" with a "debt of gratitude to Mr. Andrew Carnegie." Daily News and Leader, London and Manchester, 1909. Naval Marine Archive. 
Although the arbiters fully recognized that there was no international body creating international law, it was their responsibility to rule in accordance with accepted international practices and existing agreements between sovereign states. It was also their obligation to find a compromise acceptable to both sides. The fact that the Hague arbitrations were handled by members selected from a "permanent" panel, and that the institution was styled a "court," no doubt were intended to signal that the institution was making decisions that codified international law. This, as we have seen, was the significance of Fuller's addition of the phrase "generally speaking" in the key passage of the Muscat Dhow arbitration.

As Stephen C. Neff has pointed out in "A Short History of International Law," 38 the community of international lawyers in the late nineteenth century rejected the Hugo Grotius concept of "natural" international law, and developed the idea that international law could be derived and codified from emerging practices. Neff links this approach to the growing influence of Auguste Comte, with his "positivist" philosophy that underlay Progressive thinking in the United States and elsewhere in the era. According to Comte's philosophy, human relations, including international relations, could be organized and rationalized by codifying existing best practices.

Modern international arbitrations began with the Jay Treaty between Britain and the United States of 1794, and included, over the course of the nineteenth century, a number of arbitrations that had worked out very well. Among the most famous was the

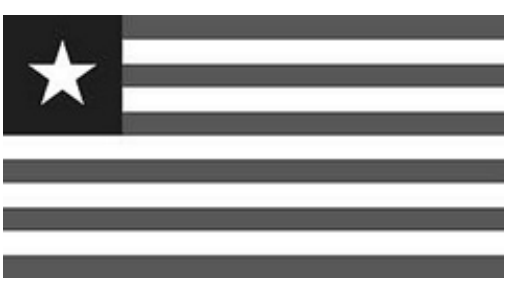

Liberian flag: white star on dark blue, red stripes on white. Alabama Claims case of 1875 that resolved U.S. claims for damages to U.S. shipping caused by British outfitting of Confederate cruisers during the Civil War. Another, more recent arbitration, that had resolved the growing British-American crisis over the boundary between British Guyana and Venezuela, had been settled in 1895. Fuller had served as the representative of the Venezuelan interests in that case, whose result perfectly matched the British, and not the Venezuelan, position. The arbitration panels in those and other early cases had been worked out on an ad hoc basis, well before the establishment of the PCA.

Neff showed that, because arbitrations had succeeded in pre-empting armed conflict, international lawyers held out hopes that a variety of institutions could be created to codify the principles that were demonstrated in arbitration, or in international multi-party treaties or conventions. The Hague Permanent Court of Arbitration was one such institution, but the Hague Conventions of 1899 and 1907 regarding warfare was another step in this process, as were the later moves to establish a League of Nations and

38 Stephen C. Neff, “A Short History of International Law," in Malcolm D. Evans, ed., International Law (Oxford: Oxford University Press, 2003), 31-58.Available online at: http://www.oup.com/uk/orc/bin/9780199565665/evans3e_ch01.pdf. See especially pp. 1417. Neff is also author of other works on the topic, including War and the Law of Nations (Cambridge: Cambridge UP, 2005). 
a World Court.

The Muscat Dhows case could be viewed as an effort to derive from best practices a sense of what constituted international law. In fact, contemporary publications regularly cited the Muscat Dhow case as an example of the evolution of international law through the practice of arbitration. ${ }^{39}$

The proclamation in the Muscat Dhows case of the "right" of a state to issue its flag to citizens of other states established an aspect of international law by deriving it from existing practice. This was why the Muscat Dhows dispute was taken to The Hague, rather than simply folded into the earlier 1904 Entente Cordiale agreements. The Entente Cordiale would not codify legal principles, especially since all its provisions were not published. By contrast, the Muscat Dhows decision was published and thus provided the basis in law for the dissociation of merchant shipping flags from the nationality of ship owners.

In the 1890s, the protégé status of native-owned, French-flagged dhows resembled the status of foreign-owned shelf corporations owning ships flying the British flag. Both represented the use of one nation's flag by ship-owners of a different nationality. For this reason, the Muscat Dhow decision had the effect of justifying both French and British practices. While the British wanted The Hague to outlaw specific protégé dhows, they certainly did not want a ruling that could be interpreted to mean that a large fraction of their own merchant fleet had no right to fly the British flag. The British had countenanced the registry and the issuance of the British flag to U.S. owned ships during the American Civil War. ${ }^{40}$ To some extent, the dominance of the British maritime flag in the late nineteenth century was due to the continued issuance of the flag to foreign owners and owners elsewhere in the British Empire. Thus, the British had reason to be doubly satisfied by the Muscat Dhows decision. It was resolved in such a way that the French could no longer issue the flag to protégés in Oman, but at the same time, the decision could be said to establish in international law that there did not have to be a link between maritime flag and personal citizenship.

In later years, when flags of convenience such as those of Liberia and Panama came under criticism from labor and some maritime groups, the fact that Britain itself accepted registries from owners abroad weakened British objections to the system. During a debate in the House of Lords in 1958 over just this issue, Viscount Runciman of Doxford remarked that Britain was in no position to complain of the lack of a genuine link between the country of registry and the ship. He stated:

I think it would be quite difficult for us in this country to complain unduly of people using other flags than their own for the purpose of reducing their costs of operation. I have only to remind your Lordships of the considerable volume of Canadian-owned

39 For example, L. Oppenheim, ed., The Collected Papers of John Westlake on Public International Law, (Cambridge: Cambridge University Press, 1915) and review by George G. Wilson, Harvard Law Review vol. 29, no. 2 (December 1915), 239-240. Westlake had discussed the Dhows case as early as 1907.

40 See Rodney Carlisle, "Flagging-Out in the American Civil War," The Northern Mariner/Le marin du nord vol. XXII, no.1 (January 2012), p.53. 
tonnage which is registered in this country at present for precisely that reason-a fact of which I do not think any of us is likely to complain. After all, to a certain point we must recognise that "fair's fair." 41

The decision that had resolved the minor conflict in Oman provided a means to confirm that British and French practices of issuing flags to foreign owners were legitimate and should be accepted in international law. Once that principle was established, it was only a few years before small states like the Free City of Danzig, Panama and Honduras, as sovereign entities, would provide their flags for low-cost ship operation for companies like ESSO and United Fruit. In more recent decades, the British red ensign, as well as the flags of small states associated with Britain, such as the Isle of Man, Bermuda, Bahamas, and others also attracted owners from many nations.

41 United Kingdom, Hansard, House of Lords Debates, p.231, 20 March 1958, http://hansard.millbanksystems.com/lords/1958/mar/20/the-mercantile-marine-1. 